\title{
Freedom, ownership and copyright: why does Kant reject the concept of intellectual property?
}

\section{Maria Chiara Pievatolo}

\author{
Copyright (C) 2009-2010 Maria Chiara Pievatolo
}

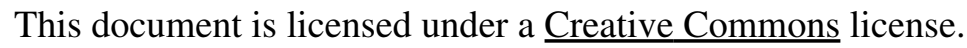

07-02-2010

Sommario

1. Introduction

2. Kant: authors right as a personal right

3. A term of comparison: Fichte's theory of intellectual property

4. What is a thing?

\section{Introduction}

In his review of Adrian Johns' latest book, Caleb Crain 1 - makes a witty remark on Kant's essay Von der Unrechtmäßigkeit des Büchernachdrucks:

\begin{abstract}
While reading Piracy, Adrian Johns's lucid but episodic history of the theft of words and ideas, I learnt that the Enlightenment philosopher Immanuel Kant once wrote an essay, little known today, explaining why it was unethical to counterfeit books. Since I was at home rather than a library when I encountered this fact, I turned to Google Books to satisfy my curiosity, and soon found there a scan of the essay's first English translation, dated 1798. It turns out that Kant didn't think that an author could mount a strong legal case against piracy based on property rights in words. After all, even after pirates copied an author's words, the author himself still had them. It was better for an author to argue that his book was not an object but an exercise of his powers which "he can concede, it is true, to others, but never alienate". In other words, Kant explained - in a passage partly obscured by the fingers of the Google technician who turned the pages in the scanner - a pirated book was not to be understood as property that had been stolen; it was rather a speech act that had been compromised. The business arrangement that an author made with an editor might make it look as if words could be traded like watches or pork bellies, but it just wasn't so.
\end{abstract}

Could there be a fitter representation of copyright's contemporary plight than the fingers of a Google technician obscuring Kant's defence of writer's rights?

The above mentioned Kant's essay was published in 1785 under the title Von der Unrechtmäßigkeit des Büchernachdrucks. Even if it has been sometimes translated as Of the injustice of counterfeiting books, its most accurate version is perhaps On the Injustice of Reprinting Books_- Kant repeated almost the same thesis in the Rechtslehre, $\S 31$, II, within Die Metaphysik der Sitten (1797). As most scholars, in the field of humanities, are still taking intellectual property for granted, the representation of Kant like an intellectual property forerunner is still a - deeply misleading - commonplace. $\stackrel{3}{-}$ 
According to Kant's Architectonic of Pure Reason the philosopher is closer to a lawgiver than to an artificer, if philosophy is considered in its Weltbegriff or cosmopolitan concept (AA.03: 542.23-30). Because such a lawgiving is based upon that reason with which every human being is endowed, the laws of reason should be thought as public laws and not as individual, private creations. How could a public law be consistently viewed as an object of private intellectual property?

Kant avoids such a contradiction because his justification of authors' right does not rely on intellectual property, but on the meaning and the function of both authors and publishers in the world of the public use of reason. Therefore, as it has been already shown, ${ }_{-}^{4}$ Kant's theory of copyright is compatible with the Weltbegriff of philosophy. Furthermore, more interestingly, it is also possible to demonstrate that it is consistent with his general theory of property, as stated in the Metaphysik der Sitten.

The following essay, after presenting a short sketch of Kant's authors right as personal right -in the traditional technical meaning of the Metaphysik der Sitten -, will introduce Fichte's theory of intellectual property to strengthen the case of Kant's rejection of intellectual property, by comparing his ideas with the theory of an actual intellectual property advocate, like Fichte himself. Eventually, to read the proposed interpretation of Kant in a wider theoretical perspective, it will attempt to connect it to his general theory of property of the Metaphysik der Sitten.

\section{Kant: authors right as a personal right}

In Kant's age, the word Nachdruck, ${ }_{-}^{5}$ sometimes translated as "counterfeiting" o "piracy", had the proper and less criminal meaning of "reprinting". The United Kingdom had passed in 1710 the first European copyright bill, the Statute of Anne, ${ }_{-}^{6}$ which received a definitive interpretation only in 1774, in the well-known judgment on Donaldson vs. Beckett 7 settled by the House of Lords. In Germany, on the contrary, the continuation of the early modern privilege ${ }_{-}^{8}$ regime and the multitude of states and jurisdictions facilitated the practice of the Nachdruck by further printers after the first publication. And it was highly controversial whether such a practice were rightful or should be considered piracy.

The debate on the Nachdruck was not restricted to publishers and lawyers: as the Enlightenment intellectuals were aware of the political importance of disseminating knowledge, major thinkers like Lessing, Kant, Fichte, Diderot, Condorcet took part to it. The concept of intellectual property was not taken for granted, even because of a strong European Roman Law tradition, according to which property is only possible on material, touchable things - the so-called res quae tangi possunt. ${ }_{-}^{9}$ The res quae tangi possunt are excludable and rivalrous; therefore they present us with the question of who is entitled to use them. On the other hand, the incorporeal, spiritual things do not need private property because they can be indefinitely shared among everyone.

Kant closes his 1785 essay by asserting his endorsement to the Roman Law tradition:

If the idea of book publishing as such which was taken as the basis for the above arguments were to be understood properly and (as I flatter myself to think it feasible) if it were to be elaborated with the requisite elegance of Roman juridical scholarship, then actions against reprinters could very well be brought before the courts without it being necessary to apply beforehand for a new law to be promulgated in this respect. $\underline{10}_{-}$

If Kant's statement has to be taken seriously, he should not be considered as an intellectual property forerunner. He reshapes the Roman Law tradition in an original way, which anticipates the continental concept of authors' moral rights.

According to Kant, a book can be seen: 
1. as a material object

2. as a means of conveying thoughts

3. as a speech

1. The book as a material object may be reprinted. It becomes a property of whoever buys it. For the very principle of private property, it is not fair to restrain the ways in which its legitimate purchaser may use it. 11

2. The Nachdruck, on the other hand, does not prevent anyone to keep on conceiving his thoughts. They remain a "property" of their author, regardless of their reproduction, because they are not material: properly speaking, ideas cannot be stolen. $\underline{12}$

3. A speech is an action (Handlung) 13 . A person who is speaking to a public is not selling anything to them: he is engaging a relationship with them. Therefore, such a relation is not a matter of rights on things (iura realia), but of personal rights (iura personalia).

In the Metaphysik der Sitten, we can find a clear distinction between ius reale and ius personale. The ius reale or ius in re is a right on things. 14 The ius personale is defined as the «possession of another's choice [Willkür], in the sense of my capacity to determine it by my own choice to a certain deed». 15 In other words, it is a right entitling someone to obtain acts from other persons. As moral subjectivity involves freedom, personal rights cannot be established without the concerned persons' consent.

According to Kant, the ius reale cannot be applied to ideas, or, better, to thoughts, because they can be conceived by everyone at the same time, without depriving their authors. Surprising as it may seem, the ius reale protects the freedom to copy, if it is taken seriously. If a thing has been purchased in a legal transaction and the purchasers copy it by their own means, they are simply working on their legitimate private property. For the very principle of private property, it is not fair to restrain the ways in which its legitimate purchaser may use it.

For this reason, no ius reale can be opposed to the reprinter. If we see the book as a material thing, whoever buys it has the right to reproduce it: after all, it is his book. Furthermore, in Kant's opinion, we cannot derive any affirmative personal obligation from a ius reale: 16 a ius personale on someone cannot be claimed by simply purchasing some related things without obtaining his or her expressed consent.

Kant, by conceiving the book as an action, adopts a strategy based on the ius personale only. By using such a strategy, he concludes that the unauthorized printer has to be compared to an unauthorized spokesperson rather than to a thief. Therefore, it is not necessary to go beyond the Roman law tradition, by inventing a new ius reale on immaterial things.

Kant's argument goes as follows: when I speak to a public, I engage a relationship with them. The book may be viewed as a medium through which authors can transmit their speeches to a wider public. In the age of printing, such a medium used to be provided by publishers. Thus publishers can be considered as spokespersons who speak in the name of the authors. But, as such, they need the authors' authorization. 17 Why? Because to speak in the name of another without his authorization is like engaging him in a relationship without his consent. As personal rights, according to Kant, concern relations among free beings, they can arise only from expressed agreements. Hence, the unauthorized printer is like an unauthorized spokesperson, who produces a relation of the author with the public without being entitled to do it.

However, the scope of Kant's justification of copyright is very narrow: it applies only to the publishing of texts, it does not touch th so-called derivative works, and it is justified only as far as it helps the public to get the texts. 
Kant does not recognize works of art as speeches. He calls works of art Werke or opera, i.e. things that are produced, while indicating books as Handlungen or operae, i.e. actions. As the works of art are simply physical objects, we can derive from Kant's assumption that every legitimate purchaser may reproduce them and may donate or sell the copies to others. $\frac{18}{-}$ Every time an object can be treated only as a product, its legitimate owner may do what he wants with it, because of his ius reale, which has to be taken seriously on both sides. Moreover, as the injustice of reprinting books depends on their communication to the public, we can deduce that their reproduction for personal use is not to be forbidden.

As regards as the derivative works, Kant states that, if one shortens, augments, retouches or translates the book of another, he produces a new speech, although the thoughts can be the same Therefore, such works cannot be seen as Nachdruck and are perfectly lawful. $\underline{19}$ In other words,in a Kantian environment, everyone may become a "wreader" - a reader and writer at the same time - without being hindered by copyright restrictions

The goal of the transaction between the author and the publisher is conveying his text to the public. The public has a right to interact with the author, if the latter has chosen to do it. According to Kant, the publisher may neither refuse to publish - or to hand over to another publisher, if he does not want to do it himself - a text of a dead author, nor release mutilated 20 or spurious works, nor print only a limited impression that does not meet the demand. If the publisher does not comply, the public has the right to force him to publish. $\frac{21}{-}$ In a Kantian environment the publisher's rights are justified only when they help authors to reach the public. Copyright should be neither censorship nor monopoly.

In the 1785 essay Kant stated that the mandate of an author to a publisher should be exclusive 22 because the publisher becomes willing to publish a book only if he is certain to earn something from it; therefore, he is interested in avoiding competition. But later, in the Metaphysik der Sitten, Kant does not mention the exclusivity requirement at all, perhaps because he has realized that it was based on an empirical contamination, depending on the current state of technology.

In Kant's world the press used to be the medium that provided for the widest distribution of ideas. Printing required both specific tools and skills, and specialized and centralized organizations. And as long as the publishers of printed texts provided the only medium to convey speeches to a wide public, Kant was inclined to bow to their interest.

However, from a conceptual perspective, there is no reason to deny that an author should be entitled to authorize everyone to distribute his work to everyone else, just like a person may hire more than one spokesperson. Such a practice is now fairly usual on the Internet, when authors choose a Creative Commons License and grant the right to publish their works to everyone, because they are interested in the widest possible spreading of their ideas. In Kant's times such a strategy would hardly be paying because the major publication technology, the press, was not cheap and easy like the digital reproduction of texts, but difficult and expensive.

Kant's thesis is based on the technical assumption that publishing requires an intermediation - just as it used to be in the age of print -, which is lawful only it has the author's consent. Where the intermediation is not necessary any longer, where no one is speaking in the name of another, copyright makes no sense. ${ }_{-}^{23}$

\section{A term of comparison: Fichte's theory of intellectual property}

In 1793 the Berlinische Monatschrift published a short essay, Proof of the Illegality of Reprinting: A Rationale and a Parable, 24 written by Fichte two years ago. The essay connects originality to intellectual property and advocates the enforcing of the latter by means of criminal sanctions. It is worth mentioning the 


\section{Freedom, ownership and copyright: why does Kant reject the concept of intellectual property?}

final parable by means of which Fichte illustrates his thesis, because it contains in itself all our commonplaces on intellectual property.

In the time of the Caliph Harun al Rashid, an alchemist used to prepare a beneficial drug and to entrust the commercial side of the business to a merchant who was the sole distributor throughout the land and who earned a goodly profit by his monopoly. Another medicine merchant stole the drug from the monopolist and started to sell it at a cheaper price. The latter brought him before the Caliph. The former pleaded for his case by arguing that his selling the drug for a cheaper price was useful to the sick persons and to the society at large. What was the judgment of the Caliph? «He had the useful man hanged». $\underline{25}$

To be accurate, the medicine merchant of the parable had not copied the drug, but had materially stolen it. Fichte suggested that copying is like stealing. In the 18th century, however, Fichte had to demonstrate the commonplace of today.

According to Fichte, we can distinguish two aspects of a book:

1. its physical aspect (das körperliche), i.e. the printed paper

2. its ideational aspect (das geistige)

The ideational aspect of a book is in turn divisible into:

a. a material aspect, i.e. the ideas the book presents;

b. the form of these ideas, i. e. the way in which they are presented.

All the aspects of a book, except one, can be appropriated by anybody: we can buy the printed paper and assimilate the ideas it conveys. We cannot, however, appropriate its form, because it is strictly personal. And, according to Fichte, it is self-evident that «we are the rightful owners of a thing, the appropriation of which by another is physically impossible». 26 As the form can be only mine, the author is the proprietor of his text and his authorized publisher is its usufructuary.

However sophistical this shift from originality to property may seem, it is not the only seminal element of our commonplaces on copyright contained in Fichte's essay. It is also worth remarking that in the Harun al Rashid parable the alchemist - the author - transfer his rights and disappears from the scene; the most powerful interests are these of a monopolist - the publisher -; only the other medicine merchant - the pirate - pleads for the interests of the public, but his arguments are rejected as criminal; as regards as the Caliph - the government -, he bows to the monopolist's interests without saying a word; and, last but not least, the criminal sanction for piracy - capital punishment - is out of all proportion.

The young Fichte believed that his ideas on authors' right were similar to the ones of Kant. 27 However, there are at least three outstanding differences between Kant and Fichte:

1. Fichte bases copyright on the individual originality in the form of expression; 28 Kant does not mention originality at all;

2. Fichte equates copyright with private property; ${ }_{2}^{29}$ Kant rejects the very possibility of founding the authors' right on a ius reale;

3. Fichte thinks that copyright violators deserve the same harsh punishment of thieves. $\frac{30}{-}$ According to Kant, the unauthorized printer should simply compensate all the damages he caused to the author or to his authorized publisher. $\frac{31}{-}$

While Fichte is an intellectual property endorser, Kant is an "enlightened" conservative who supports the Roman law tradition, against the propertization trend. He accepts the copyright principle, according to which 


\section{Freedom, ownership and copyright: why does Kant reject the concept of intellectual property?}

authors are entitled to decide how to publish their works. The rights of the publishers, however, are justified only as long as they help authors to reach the public, while the personal use of the texts and the so-called "wreading" should remain free. And, above all, all that can be viewed as a product is, in his opinion, outside the scope of copyright and may be copied without restrictions.

What is, in any, the philosophical meaning of Kant's "conservatism"? To answer such a question, we need to link his ideas on authors' right to his general theory of property, as it is explained in the Metaphysics of Morals.

\section{What is a thing?}

In the Metaphysics of Morals, Kant seems to take for granted that the objects of real rights are only corporeal entities or res corporales: «Sache ist ein Ding, was keiner Zurechnung fähig ist. Ein jedes Object der freien Willkür, welches selbst der Freiheit ermangelt, heiß daher Sache (res corporalis)». $\frac{32}{-}$ Theoretically, however, such a negative definition could have been appropriate to incorporeal things as well.

According to Kant, the rightful possession of a thing should be distinguished from its sensible possession. Something external would be rightfully mine «only if I may assume that i could be wronged by another's use of a thing even though I am not in possession of it» (AA.06 245:13-16). The rightful possession is an intelligible, not sensible, relation. I can claim that my bicycle is mine only if I am entitled to require that nobody takes it even when I leave it alone in the backyard.

Kant's theory of property is very different from Fichte's principle of property as explained in his 1793 essay, according to which we are the rightful owners of a thing, the appropriation of which by another is physically impossible. For this reason, according to Fichte, the originality of the exposition entitles an author to claim a rightful property on his work.

Is it really so obvious that originality implies property? Property is a comfortable social convention that allows us to avoid to quarrel all the time over the use of material objects. It is so comfortable just because it is physically possible to appropriate things; we do not need to invoke property when something cannot be separated from someone. I say both that my fingerprints or my writing style are "mine" and that my bicycle is "mine". But these two "mine" have a different meaning: the former is the "mine" of attribution; the latter is the "mine" of property. The former can be used to identify someone, and conveys the historical circumstance that something is related exclusively to someone; the latter points only to an accidental relation with an external thing, if we consider it from a physical point of view.

It is possible to lie on a historical circumstance, by plagiarizing a text, i.e. by attributing it to a person who did not wrote it. However, properly speaking, no one can "steal" the historical connection between "my" writing style and me: the convention of property is useless, in this case. Besides, if Fichte's principle were the only justification of property right, it would undermine the very concept of it: as it is physically possible to "attribute" my bicycle to another, when I leave it alone in the backyard, everyone would be entitled to take it for himself. As Kant would have said, a legal property right cannot be founded on sensible situations, but only on intelligible relations.

Although he defines things as res corporales, Kant determines the rightful possession of a thing as a possession without detentio, by ignoring all its sensible facets. Such a possession - a possession of a thing without holding it - is exerted on an object that is "merely distinct from me", regardless of its position in space and time. Space and time, indeed, are sensible determinations and should be left out of consideration.

According to the postulate of practical reason with regard to rights, property is justified by a permissive law of reason: 33 if a rightful possession were not possible, every object would be a res nullius and nobody would be 


\section{Freedom, ownership and copyright: why does Kant reject the concept of intellectual property?}

entitled to use it.

Kant implicitly denies that a res nullius can be used by everyone at the same time. His tacit assumption suggests that the objects of property, besides being distinct from the subjects, are excludable and rivalrous as well, just like the res corporales.

Kant asserts that something external is mine if I would be wronged by being disturbed in my use of it even though I am not in possession of it (AA.6, 249:5-7). If property is a merely intelligible relation with an object that is simply distinct from the subject, we have no reason to deny that such an object might be immaterial as well, just like the objects of intellectual property. Why, then, does Kant refrain from using the very concept of it?

According to him, a speech is an action of a person: it belongs to the realm of personal rights. A person who is speaking to the people is engaging a relationship with them; if someone else engages such a relationship in his name, he needs his authorization. The reprinter, as it were, does not play with property: he is only an agent without authority. Speeches, by Kant, cannot be separated from persons: he has seen the unholy promised land of intellectual property without entering it.

According to Kant, before the acquired rights, everyone has a moral capacity for putting others under obligation that he calls innate right or internal meum vel tuum (AA.06, 237:24-25). The innate right is only one: freedom as independence from being constrained by another's choice, insofar it can coexist with the freedom of every other in accordance with a universal law.

Freedom belongs to every human being by virtue of his humanity: in other words, it has to be assumed before every civil constitution, because it is the very possibility condition of law. Freedom implies innate equality, «that is, independence from being bound by others to more than one can in turn bind them; hence a human being's quality of being his own master (sui iuris), as well as being a human being beyond reproach (iusti) since before he performs any act affecting rights he has done no wrong to anyone, and finally his being authorized to do to others anything that does not in itself diminish what is theirs, so long as they do not want to accept it - such things as merely communicating his thoughts to them.» (AA.06, 237-238) $\underline{34}$

In spite of his intellectual theory of property, 35 Kant does not enter in the realm of intellectual property for a strong systematic reason. Liberty of speech is an important part of the innate right of freedom. It cannot be suppressed without suppressing freedom itself. If the ius reale were applied to speeches, a basic element of freedom would be reduced to an alienable thing, making it easy to mix copyright protection and censorship. $\frac{36}{-}$

Property rights are based on the assumption that its objects are excludable and rivalrous and need to be appropriated by someone to be used. We cannot, however, deal with speeches as they were excludable and rivalrous things that need to be appropriated to be of some use, because excluding people from speeches would be like excluding them from freedom.

Therefore, Kant binds speeches to the persons and their actions, and limits the scope of copyright to publishing, or, better, to the publishing of the age of print: the Nachdruck is unjust only when someone reproduces a text without the author's permission and distributes its copies to the public. If someone copies a book for his personal use, or lets others do it, or translates and elaborates a text, there is no copyright violation, just because it is not involved any intrinsic property right, but only the exercise of the innate right of freedom. The boundary of Kant's copyright is the public use of reason, as a key element of a basic right that should be recognized to everyone. Kant does not stick to the Roman Law tradition because of conservatism, but because of Enlightenment. 
${ }^{[1]}$ C. Crain, «Terms of infringement: battling intellectual piracy», The National, January 21, 2010

[2] The Cambridge University site Primary Sources on Copyright (1450-1900) translates it as On the Unlawfulness of Reprinting. Cambridge commentary, written by Friedemann Kawohl (Commentary on Kant's essay On the Injustice of Reprinting Books (1785), in Primary Sources on Copyright (1450-1900), eds L. Bently \& M. Kretschmer, www.copyrighthistory.org) offers a remarkably faithful interpretation of Kant's ideas on copyright: «Kant denies the concept of "intellectual property" and the idea that any intellectual content is materialised in the book as such. In Kant's view the book is a medium, a mere tool for conveying the author's thoughts, and thus an unlicensed reprint does not encroach on any property as such of the author or publisher. Rather, it is unlawful because it amounts to an 'agency without authority'».

[3] See for instance W.W. Fisher III, «Theories of Intellectual Property», in S. Munzer, ed., New Essays in the Legal and Political Theory of Property (Cambridge University Press, 2001) M. Borghi, Writing Practices in the Privilege - and Intellectual Property - Systems, Social Science Research Network Working Paper Series, 2003. Besides, see the critical review of M.C. Pievatolo to R. Pozzo (a cura di), I. Kant, J.G. Fichte, J.A.H. Reimarus, L'autore e i suoi diritti. Scritti polemici sulla proprietà intellettuale, Milano, Biblioteca di via Senato, 2005. ReF - Recensioni filosofiche (nuova serie), 5. 2006 According to R. Pozzo, both Kant and Fichte can be viewed as intellectual property forerunners, so that its idea has to be connected to - and ennobled by - the very flower of German Enlightenment. It is perhaps worth remarking that the president of the Biblioteca di via Senato is Marcello Dell'Utri, a senior advisor of the powerful Italian politician and media oligopolist Silvio Berlusconi.

[4] See M.C. Pievatolo, Publicness and Private Intellectual Property in Kant's Political Thought in Recht und Frieden in der Philosophie Kants. Akten des X. Internationalen Kant-Kongresses, hrsg. von Valerio Rohden, Ricardo R. Terra, Guido A. de Almeida u. Margit Ruffing, de Gruyter, Berlin New York 2008 Bd. 4, pp. 631-641.

[5] Check its definition <http://germazope.uni-trier.de/Projects/WBB/woerterbuecher/dwb/wbgui?lemid=GN00274 > in J. Grimm and W. Grimm. Deutsches Wörterbuch, Lepzig: S. Hirzel, 1854-1960.

[6] The Statute copyright was no longer a grant from the crown: it was recognized as an original right of the author. It was limited in time, with a 21 years term for all works already in print at the time of its enactment and a 14 years term for all works published subsequently.

[7] See Donaldson v. Beckett. Proceedings in the Lords on the Question of Literary Property, February 4 through February 22, 1774, in K.-E, Tallmo, The History of Copyright: A Critical Overview With Source Texts in Five Languages at $<$ http://www.copyrighthistory.com/donaldson.html $>$

[8] The major difference between copyright and privilege is that the former is a universal right, while the latter depends on a grant from the Crown. The former, in other words, is due to every author, while the latter derives from a decision of the political power.

[9] In the "battle of the booksellers" that raged in England for more than half a century, Roman Law tradition was an important landmark. While the English booksellers argued that copyright was a common law property, therefore unlimited and perpetual, the Scottish booksellers recognized only the Statute of Anne terms on the basis of the Scottish Roman Law tradition that denied the very possibility of property on immaterial objects. In Roman Law, indeed, property or «dominium properly signifies the right of dealing with a corporeal thing as a person (dominus) pleases». Although some merely social norms did protect authors' moral rights prior to the publication, «nowhere in the documents of Roman law-neither in the Corpus Iuris Civilis nor in the juridical 
Freedom, ownership and copyright: why does Kant reject the concept of intellectual property?

fragments which have come down to us - is a law to be found or a case where an author appeared in a court of law to protest the unlicensed or otherwise illegitimate publication of a work» (K. de la Durantaye, «The origins of the protection of literary authorship in ancient Rome», Boston University International Law Journal , vol. 25 , no. 1,2007 , p. 59 )

[10] I Kant, Von der Unrechtmäßigkeit des Büchernachdrucks, AA.8, 87:09-14. The translation is by Luis Sundkvist, adapted from John Richardson's anonymous translation of 1799, now in the Cambridge University site Primary Sources on Copyright (1450-1900) < http://www.copyrighthistory.org/htdocs/index.html>.

[11] VUB , AA.08 79:10-13.

[12] Ibidem, AA.08 9ㅜ:08-10

[13] Ibidem, AA.08 $\underline{85-86}$.

[14] §11, MS, AA.06 260:. The English translations from the Metaphysik der Sitten are by M. Gregor: I. Kant, The Metaphysics of Morals, Cambridge, Cambridge U.P., 1996.

[15] §18, MS, AA.06 271:04-10. According to R. Pozzo («Immanuel Kant on intellectual property». Trans/Form/Ação 29 (2), 2006), Kant's copyright belongs to the family of personal rights, in the current meaning of rights pertaining to the person, like the rights of a personal security, personal liberty, and private property. Such an interpretation contrasts with the definition of ius personale contained in the Metaphysik der Sitten and gives the readers the misleading impression that Kant intended copyright as a basic human right.

[16] VUB, AA.08 $\underline{83}$.

[17] VUB, AA.08 79-82.

[18] Ibidem, AA.08 $\underline{85-86}$.

[19] Ibidem, AA.08 $\underline{86-87 .}$

[20] In a Kantian enviroment, «the fingers of a Google technician obscuring Kant's defence of writer's rights» would violate authors' right and betray the very function of publishers. What is the use of a copyright that makes it difficult the dissemination of ideas, instead of promotinjg it?

[21] Ibidem, AA.08 $\underline{85}$.

[22] Ibidem, AA.08 $\underline{81}$.

[23] In a Kantian environment, controversial sites like The Pirate Bay, as they are only facilitating people to copy materials for their personal use, should not be seen as a "pirate" Nachdrucker.

[24] An English translation by Martha Woodmansee can be downloaded at the URL $<$ http://www.case.edu/affil/sce/authorship/Fichte, Proof.doc $>$

[25] J.G. Fichte, Beweis, p. 482.

[26] J.G. Fichte, Beweis, pp. 446 ff. 
Freedom, ownership and copyright: why does Kant reject the concept of intellectual property?

[27] J.G. Fichte, Beweis, ftn. 1. According to Fichte, Kant did not intend the opera as an action, but as something determined by the author's spiritual form.

[28] Ibidem, p. 1.

[29] Ibidem, p. 1 .

[30] Ibidem, pp. 8-10.

[31] I. Kant, Über den Gemeinspruch Das mag in der Theorie richtig sein, taugt aber nicht für die Praxis, AA. $08 \underline{80}$.

[32] "A thing is that to which nothing can be imputed. Any object of free choice which itself lacks freedom is therefore called a thing (res corporalis)" (AA.06, 223 $)$.

[33] See B. Tierney, «Kant on Property: The Problem of Permissive Law,» Journal of the History of Ideas, 62(2), 2001, pp. 301-312 and «Permissive Natural Law and Property: Gratian to Kan»t, Journal of the History of Ideas 62(3), 2001, pp. 381-399.

[34] Italics added.

${ }^{[35]}$ See H. Williams, Metaphysical and not just political, "ECPR general conference" (September 2007)

[36] According to Michael Goldhammer (Theoretical perspectives of a one right system - a Kantian approach. Helsinki, 2008), it could be possible to produce an intellectual property justification on the basis of Kant's intellectual theory of property: «if the relationship to the apple in my hand is nothing else than my innate freedom, why shouldn't I have a similar, or even equal, relationship to my expressed thoughts?» Differently form Pozzo, Goldhammer is well aware that his Kantian approach is not rooted in Kant's works. His attempt, however interesting, is exposed to the objection that «my expressed thoughts» - as non rivalrous and non excludable things - can be used by me and by everyone else at the same time, without depriving anyone of anything. 